\title{
Fulgor do nada
}

Glow of the Nothing

\author{
Alfredo Schechtman* \\ Brasília, Brasil \\ alfredo_schechtman@yahoo.com.br
}

Blues

No espelho baço,

esmaecido,

o fulgor do Nada.

Imagem

No baço espelho, refletido,

o fulgor do Nada.

Âmago

No baço espelho,

o fulgor do Nada.

Recebido em: 17/02/2018.

Aprovado em: 19/03/2018.

* Mestre em Medicina Social pelo Instituto de Medicina Social da Universidade do Estado do Rio de Janeiro (UERJ), médico e poeta. 